\title{
Pelaksanaan Dan Penguatkuasaan Halal Di Malaysia
}

\author{
Muhammad Hafiz Badarulzaman, Harlida Abdul Wahab, Alias Azhar, Nurretina Ahmad Shariff \\ Pusat Pengajian Undang-Undang, UUM COLGIS, Universiti Utara Malaysia 06010, Sintok, Kedah, Malaysia
}

*Corresponding author: mdhafiz@uum.edu.my

\begin{abstract}
The enforcement agency is one of the bodies that responsible for the issue of halal. Each agency is authorized by the respective statute and enactment in enforcing the regulation and law on halal goods and products. Although the implementation and enforcement of halal in Malaysia is seen as comprehensive, the issues on weakness and lameness of the agencies are still being debated especially matters related to procedures and conflict of jurisdictions. This paper focuses on the jurisdiction of the enforcement agencies pertaining to halal matters. The paper also will discuss and elaborate the legal issues and hiccups due to halal. Firstly, the jurisdiction of enforcement agencies will be discussed throughout this paper. Then this paper will analyze the procedures and statutory provisions as to see whether all the processes and current legislations are protecting the consumers on halal food consumption. Notwithstanding of statutory provisions, the finding of this paper is based on interviews with the enforcement agencies of halal products. A few recommendations have been suggested as to improve the lacuna pursuant to the roles and jurisdictions of the enforcement agencies.
\end{abstract}

Keywords: Consumer, law, halal, foods product, syariah

\begin{abstract}
Abstrak
Agensi pelaksana dan penguatkuasa merupakan antara badan yang bertanggungjawab penuh dalam isu halal. Setiap agensi diberikan kuasa melalui akta dan enakmen tersendiri dalam menguatkuasakan undang-undang terhadap barangan dan produk halal. Walaupun pelaksanaan dan penguatkuasaan halal di Malaysia dilihat sebagai mantap, isu-isu tentang kelemahan dan ketempangan agensi masih terus diperkatakan terutama perkara yang melibatkan prosedurprosedur dan percanggahan bidang tugas. Kertas kerja ini memberikan fokus terhadap bidang kuasa agensi penguatkuasa kerajaan terhadap hal-hal berkaitan halal. Perbincangan kertas kerja akan turut menghuraikan isu dan masalah perundangan berkaitan halal. Perkara pertama yang akan dibincangkan ialah bidangkuasa agensi penguatkuasa dan pelaksana. Perkara ini seterusnya akan dikaitkan dengan prosedur-prosedur dan peruntukan undang-undang bagi melihat sama ada prosedur dan undang-undang sedia ada melindungi pengguna dari sudut penggunaan makanan halal. Selain daripada peruntukan undang-undang, dapatan ini merupakan hasil temubual bersama pihak agensi pelaksana dan penguatkuasa bagi produk halal. Bebarapa cadangan dikemukan untuk proses penambahbaikan terhadap lacuna dalam bidang kuasa dan peranan agensi penguatkuasa.
\end{abstract}

Keywords: Pengguna, undang-undang, halal, produk makanan, syariah

(C) 2016 Penerbit UTM Press. All rights reserved

\subsection{PENDAHULUAN}

Isu halal merupakan perkara yang sangat penting kerana ia berkembang dan sentiasa diperkatakan dari semasa ke semasa. Peniaga dan pengeluar perlu prihatin terhadap permasalahan halal kerana ia membabitkan ramai pengguna Islam di Malaysia. Secara realitinya, terdapat banyak kalangan peniaga dan pengeluar yang gagal mematuhi prosedur yang ditetapkan. Ini kerana, mereka lebih mencari keuntungan daripada mengutamakan kebajikan. Usaha gigih pihak-pihak berwajib seperti Jabatan kemajuan Islam Malaysia (JAKIM), Majlis Agama Islam Negeri (MAIN), Jabatan Agama Islam Negeri (JAIN), Kementerian Perdagangan dalam Negeri, Koperasi dan Kepenggunaan (KPDNKK), Jabatan Kesihatan dan lain-lain dalam memastikan penguatkuasaan halal Malaysia memenuhi standard dan piawaian halalan toyyiban perlu dipuji dan disokong. Para pengusaha dan peniaga perlu berusaha ke arah merealisasikan budaya pengeluaran dan penawaran produk makanan yang memenuhi kriteria halal, berkualiti dan baik. Sehubungan itu, dalam meneliti permasalahan halal, bidang tugas dan penguatkuasaan di pihak agensi pelaksana wajar dilihat dan diteliti bagi mengetahui proses dan prosedur yang dilaksanakan, dan sebarang permasalahan dan kepincangan yang dikenal pasti akan dapat dibincangkan bagi tujuan penambahbaikan demi maslahah bersama.

\subsection{BIDANG KUASA AGENSI PENGUATKUASA}

Agensi pelaksana dan penguatkuasa kerajaan merupakan antara badan penguatkuasa yang bertanggungjawab penuh dalam isu halal. Setiap agensi ini mempunyai akta dan enakmen tersendiri dalam menguatkuasakan undang-undang terhadap barangan dan produk halal. Bagi tujuan perbincangan ini, peranan dan bidang kuasa Kementerian Perdagangan Dalam Negeri, Koperasi dan Kepenggunaan (KPDNKK), Jabatan Kesihatan Negeri Kedah, Jabatan Kemajuan Islam Malaysia (JAKIM) dan Jabatan Mufti Negeri Kedah akan diteliti. 
Kementerian Perdagangan Dalam Negeri, Koperasi dan Kepenggunaan (KPDNKK)

KPDNKK berfungsi menggubal dasar, strategi, dan mengkaji perkara-perkara berkaitan dengan pembangunan perdagangan dalam negeri dan kepenggunaan. Bidang tugasnya termasuk melaksanakan program pendidikan pengguna, memperkukuhkan program kesedaran dan perlindungan pengguna serta membantu gerakan kepenggunaan. Kementerian ini bertanggungjawab penuh dalam label dan penandaan halal. Undang-undang utama yang berkaitan dengan perkara halal dan diletakkan di bawah peguatkuasaannya adalah Akta Perihal Dagangan 2011, khususnya melalui Perintah Perihal Dagangan (Takrif Halal) 2011 dan Perintah Perihal Dagangan (Perakuan dan Penandaan Halal) 2011.

\section{Jabatan Kesihatan Negeri Kedah}

Jabatan Kesihatan negeri Kedah ditubuhkan di bawah Kementerian Kesihatan Malaysia. Di Jabatan Kesihatan negeri ini terdapat Bahagian Keselamatan dan Kualiti Makanan yang berfungsi melaksanakan aktiviti pemantauan keselamatan makanan dari segala aspek kualiti mengikut prosedur yang ditetapkan. Jabatan ini akan memastikan makanan yang dijual kepada orang ramai adalah bersih, selamat dan berkualiti untuk dimakan. Keselamatan makanan adalah merangkumi aspek pemilihan bahan mentah, penyimpanan bahan mentah, penyediaan (pemprosesan), pengendalian, penjualan dan penyimpanan produk yang siap diproses. Jabatan Kesihatan melaksanakan fungsi pemantauan keselamatan makanan ini selaras dengan piawaian halalan toyyiba.

\section{Jabatan Kemajuan Islam Malaysia (JAKIM)}

Jabatan Kemajuan Islam Malaysia (JAKIM) memberi fokus kepada aspek penguatkuasaan undang-undang berkaitan halal. Badan ini diberikan amanah sebagai badan pengawal piawaian halal semenjak Ogos 2009. Penglibatan JAKIM dalam memberi pengesahan status halal kepada produk makanan dan barangan gunaan Islam di negara ini bermula sejak 1974. Perkembangan pesat industri makanan di negara ini dan keperluan semasa umat Islam, maka berlaku pelbagai perubahan polisi dan dasar tentang fungsi dan bidang kuasa penguatkuasa halal. Secara umumnya, perubahan keputusan yang dibuat oleh pihak Kerajaan bermatlamatkan masalih mursalah (kepentingan awam) berkaitan kepenggunan halal di Malaysia. Maklumat dan panduan halal secara talian (online) merupakan inisiatif terkini dilakukan oleh pihak JAKIM.

\section{Jabatan Mufti Negeri Kedah}

Jabatan Mufti Negeri Kedah telah ditubuhkan berdasarkan Enakmen Mufti dan Fatwa (Kedah Darul Aman) 2008 telah diluluskan di dalam Dewan Undangan Negeri Kedah Darul Aman setelah mendapat perkenan KDYMM Tuanku Sultan. Pentadbiran institusi fatwa di Negeri Kedah diperkemaskan lagi dengan keanggotaan Jawatankuasa Fatwa yang terdiri daripada Mufti sebagai Pengerusi, Timbalan Mufti sebagai ahli, tiga orang anggota Majlis, dan tidak kurang daripada dua dan tidak lebih daripada enam orang yang lain. Fungsi utama jabatan ini adalah sebagai agensi yang menyelaras dan membangun fatwa yang mantap berpandukan Al Quran dan As Sunnah, Ijma'dan Qias berpegang kepada Aqidah Ahlus Sunnah Wal Jamaah.

\subsection{ISU DAN MASALAH OLEH BADAN PENGUATKUASA}

KPDNKK menghadapi masalah dari sudut penguatkuasaan kerana bilangan pegawai dan anggota yang terhad. Sebagai contoh, anggota penguatkuasa di negeri Kedah adalah seramai 150 orang dengan 50 orang ditempatkan di Alor Setar (Pegawai KPDNKK, 2012). Bilangan ini agak kecil jika dibandingkan dengan bidang kuasa KPDNKK yang pelbagai meliputi aspek perdagangan dalam negeri termasuk jualan langsung, kepenggunaan dan koperasi. Di samping itu, prosedur pendakwaan turut menjadi isu. Kelewatan proses yang dijalankan kerana mengambil masa yang panjang dalam menganalisis sampel, selain masalah dari segi standard sampel yang dihantar untuk dianalisis di samping masalah logistik yang menyukarkan menyebabkan pendakwaan sukar dibuktikan. Lebih-lebih lagi apabila berlaku kerosakan pada sampel yang diambil akibat daripada proses dan prosedur yang panjang tadi ((Pegawai KPDNKK, 2012).

Selain itu, masalah pembuktian juga menjadi sukar apabila melibatkan bahan mentah seperti ayam yang mati akibat daripada penyembelihan yang tidak sempurna. Proses dan prosedur yang panjang menyukarkan pendakwaan dibuat apabila ia melibatkan barangan yang mudah rosak. Keadaan ini boleh menyebabkan pengusaha atau peniaga terlepas daripada dakwaan seterusnya mengenepi langsung kepentingan pengguna.

Masalah utama lain termasuk aspek penggunaan logo halal pada premis atau bahagian-bahagian tertentu premis seperti dapur dan restoran. Berhubung dengan perkara ini, pihak KPDNKK tidak dapat mengambil tindakan terhadap restoran yang tidak mempunyai logo halal kerana bidang kuasa KPDNKK hanya terhadap label dan penandaan halal terhadap premis dan produk.

Bagi Jabatan Kesihatan, undang-undang yang sedia ada bersifat tidak menyeluruh dan merangkumi bidang kuasa yang berasingan. Meskipun Jabatan Kesihatan menggunakan Akta Makanan 1983 dan Peraturan-peraturan Makanan 1985 untuk pelaksanaan semua dasar, polisi dan strategi berhubung dengan pemantauan makanan, namun terdapat beberapa undang-undang lain yang terpakai dalam menangani masalah produk makanan halal seperti Akta Perlindungan Pengguna 1999 dan Akta Perihal Dagangan 2011 yang mana kedua-dua undang-undang ini bukanlah memperuntukkan kuasa kepada Jabatan Kesihatan. Sedangkan, dari segi istilah halal, pengguna amat maklum bahawa halal bukanlah satu-satunya perkara yang dititikberatkan malah ia sewajarnya merangkumi aspek toyyiba yakni bersih dan suci. Produk makanan yang halal semata-mata tanpa menitikberatkan sudut kebersihan tidak dapat memenuhi piawaian halal yang sebenar. Namun dengan kuasa Jabatan Kesihatan yang terhad kepada kebersihan, ia seolah-olah menafikan penyatuan halal dan toyyiba yang sewajarnya menepati konsep halal. Sehingga kini tiada satu Akta yang komprehensif yang mengawal selia semua isu-isu makanan halal di Malaysia.

Unit Makmal (Analisis Makanan) di Jabatan Kesihatan bertanggungjawab mengawal selia serta menyelaras semua aktiviti dan perkhidmatan makanan yang dibekalkan (Akta Makanan 1985). Makanan yang diambil sebagai sample akan dianalisa di makmal Jabatan Kesihatan. Bagi memeriksa kehalalan produk makanan pula, JAKIM turut mempunyai makmal tersendiri bagi tujuan menganalisis sampel di mana JAKIM akan menghantar sampel produk makanan ke Jabatan Kimia MOSTI. Di sini terdapat masalah teknikal antara Jabatan Kesihatan dan JAKIM apabila kedua-dua jabatan ini mempunyai dua makmal yang berbeza dan menggunakan standard serta proses yang 
berbeza. Ini menyebabkan dapatan analisis makanan daripada kedua-dua makmal ini bercanggah dan tidak sama sungguhpun sampel produk makanan yang dianalisis adalah dari jenis, label dan jenama yang sama. Dalam aspek makanan halal, sekiranya terdapat pertindihan hasil dapatan analisa makmal daripada JAKIM dan Jabatan Kesihatan, maka hasil dapatan daripada JAKIM yang akan terpakai kerana JAKIM tidak mengiktiraf dapatan daripada makmal yang selain daripada makmal rasmi mereka, yakni Jabatan Kimia MOSTI.

Mengikut pandangan pihak JAKIM, pengeluar perlu mengisytiharkan ramuan-ramuan yang digunakan dan ramuan-ramuan itu mesti halal. Namun timbul keadaan tertentu apabila sebahagian ramuan yang digunakan adalah kritikal di mana pembekal yang menawarkan barangan tersebut pada harga murah namun pengeluar tersebut tiada logo halal. Sebagai contoh, barangan yang terdedah kepada risiko tidak halal adalah 'food supplement' yang menggunakan gelatin termasuk dalam kategori bahan kritikal. Bahan yang menggunakan sumber daripada haiwan sepatutnya mendapat pengesahan halal dan sumber tersebut mesti jelas. Ini menyukarkan pihak JAKIM kerana JAKIM hanya akan bertindak berdasarkan aduan pengguna.

Jabatan Mufti bertanggungjawab dalam mengeluarkan fatwa. Fatwa penting dalam sejarah perundangan Islam. Fatwa yang dikeluarkan adalah berdasarkan hujah dan dalil syarak, iaitu dengan menggunakan kekuatan Istinbat. Sekiranya sesuatu fatwa dikeluarkan menurut hawa nafsu atau akal fikiran, ia bukanlah fatwa dalam erti kata yang sebenar. Ini menunjukkan proses mengeluarkan fatwa adalah sesuatu yang rumit dan perlu mengikut prosedur-prosedur yang telah ditetapkan. Jabatan Mufti pernah diadukan persoalan berkaitan isu ikan keli yang diberi makan sumber yang haram seperti usus dan najis babi, Timbalan Mufti berpendapat ianya isu tanggungjawab penternak atau pengusaha dan pembekal serta peniaga. Hukum ikan keli atau ternakan yang lain diberikan makan sumber yang haram bergantung kepada niat penternak atau pengusaha tersebut. Jika sengaja memilih sumber yang haram sedangkan masih ada pilihan yang halal, hukumnya adalah haram perbuatannya dan juga makan hasil ternakannya. Pembekal dan peniaga perlu berusaha memastikan status halal dan haram ikan keli tersebut sebelum melakukan transaksi urusniaga.

\subsection{CADANGAN DAN KESIMPULAN}

Kerajaan perlu mengambil langkah proaktif dengan mewujudkan akta baru iaitu Akta Halal yang lebih bersifat komprehensif. Akta tersebut telah dicadangkan oleh pelbagai pihak termasuk agnesi kerajaan dan badan bukan kerajaan. Ini kerana melalui akta tersebut, pihak JAKIM mampu bertindak atas kapasitinya sendiri. Namun dari segi sumber manusia, pihak kerajaan perlu menambah bilangan penguatkuasa JAKIM untuk menjalankan tugas statutori mereka. JAKIM juga dicadangkan untuk memasukkan logo halal dalam bentuk skor A, B dan C. Skor ini dapat memberikan gambaran tentang piawai halal yang terbaik, sederhana dan lemah oleh pengeluar. Maka pengguna berpeluang untuk menilai dan memilih sendiri produk yang diingini seperti yang diamalkan oleh Jabatan Kesihatan Negeri terhadap kebersihan premis makanan.

Selain itu, pindaan yang telah dibuat terhadap Akta Perihal Dagangan 2011 belum begitu mencukupi untuk menangai masalah berkaitan isu halal. Hanya separuh perlindungan diberikan melalui pindaan tersebut. Hal ini bergantung kepada beban tugas KPDNKK yang bertanggungjawab untuk mendakwa sebarang salahguna logo halal apabila disahkan oleh pihak JAKIM. Bahkan bidang kuasa KPDNKK yang terlampau luas yang mencakupi isu industri, koperasi dan kepenggunaan boleh meremehkan isu halal. Oleh yang demikian, pemisahan kuasa KPDNKK perlu disegerakan dan dipecahkan kepada dua kementerian yang berbeza. Masing-masing kementerian akan membela hak pengguna dan membela hak industri pengeluar.

Di samping itu, factor-faktor utama yang mendorong kearah berlakunya pengabaian hak pengguna ialah faktor komersial dan faktor kurang kefahaman tuntutan syariat. Pengeluar lebih mengutamakan perniagaan dan keuntungan. Mereka mahu memaksimakan keuntungan dan meminimakan kerugian. Apabila diwujudkan piawaian sijil halal, pengeluar terpaksa menanggung sedikit kerugian dengan memilih bahan dan sumber mentah yang hanya disahkan oleh JAKIM dan harganya jauh lebih tinggi di pasaran berbanding bahan mentah yang sumber halalnya diragui. Manakala faktor kedua, berhubung dengan tuntutan syariat. Kebanyakan pengeluar terdiri daripada orang bukan Muslim dan mereka tidak memahami bahawa halal merupakan satu tuntutan syariat dan wajib dipenuhi oleh pengeluar. Oleh itu, pendedahan tentang isu halal ini perlu diperbanyakkan dan agensi berwajib perlu menganjurkan perlbagai seminar berkaitan halal kepada pengeluar.

\section{Rujukan}

Akta Perihal Dagangan 2011

Akta Makanan 1983 dan Peraturan Makanan 1985

Perintah Perihal Dagangan (Takrif Halal) 2011

Perintah Perihal Dagangan (Perakuan dan Penandaan Halal) 2011

Portal halal Malaysia, terdapat di http://www.halal.gov.my/

Portal Kementerian Perdagangan Dalam Negeri, Koperasi dan Kepenggunaan, terdapat di http://www.kpdnkk.gov.my/

Temubual, Tuan Haji Sakri Saleh, Pengarah KPDNKK Negeri Kedah, 18 Julai 2012.

Temubual, Encik Fadhil bin Hasan, Penolong Pegawai Penguatkuasa, KPDNKK Negeri Kedah, 18 Julai, 2012.

Temubual, Encik Mohd Khairuddin Bin Mohd Talib, Timbalan Pengarah kesihatan Negeri, Jabatan Kesihatan Negeri Kedah, 19 Julai, 2012.

Temubual, Sheikh Marwazi Bin Dziyauddin, Timbalan Mufti Kedah, Jabatan Mufti Negeri Kedah, 18 Julai, 2012. 